УДК 351.72.07:336.148](4-6€C+477)

DOI https://doi.org/10.32838/2663-6468/2020.1/15

\title{
Юрійчук С.П.
}

Чернівецький національний університет імені Юрія Федьковича

\section{Свірнюк Н.В.}

Чернівецький національний університет імені Юрія Федьковича

\section{ІНСТИТУЦЙНІ ОСОБЛИВОСТІ РАХУНКОВОЇ ПАЛАТИ ЯК СУБ'ЄКТА ПАРЛАМЕНТСЬКОГО КОНТРОЛЮ В КРАЇ̈АХ ЄС ТА УКРАЇ̈I}

У статті проаналізовано діяльність спеціального органу реалізації парламентського контролю - Рахункової палати у Німеччині, Франиії, Фінляндії та Україні, щзо свідчить про поступове їх інституиійне уподібнення, наближення до міжнародних та європейських стандартів фінансового контролю, поступовий перехід до виконання функиії фінансово-економічного контролю в контексті ефективності використання бюджетних коштів.

Донедавна контрольна діяльність Рахункової палати України (РПУ) була малоефективна, непрозора, здійснювалася тільки на начіональному рівні виключно за використанням коштів Державного бюджету.

Парламентський аудит фінансової діяльності органів влади на місиевому рівні став можливим унаслідок реалізаиї реформи місцевого самоврядування та децентралізачії через функціонування територіальних управлінь у регіонах України, які покликані забезпечувати незалежний від місиевих органів влади зовнішній контроль бюджетів як на стадії їх проектування, так і виконання.

Із позитивного закордонного досвіду для впровадження в Украӥні можна рекомендувати:

- в умовах парламентсько-президентської форми правління розширити сфери впливу РПУ не тільки на управління бюджетом, а й на всю економічну діяльність;

- закріпити за РПУ функиію попереднього консультування щуодо фінансової діяльності;

- передбачити в організаційній структурі РПУ орган прокуратури;

- закріпити за РПУ повноваження контролю фінансування виборів та політичних партій.

Ключові слова: контроль, парламентський контроль, фінансовий контроль, рахункова палата, конституціоналізм.

Постановка проблеми. Парламентський контроль уже давно закріплено в теорії конституціоналізму як обов'язковий складник правового регулювання взаємодії та взаємостримування гілок влади демократичної держави. Серед таких засобів стримування найвагомішими традиційно визнають фінансові засоби контролю, а особливо - бюджетний пріоритет, тобто право парламенту затверджувати прибутки та видатки держави, здійснювати контроль за виконанням бюджету, приймати рішення щодо звіту про його виконання. Загальновідомо, що бюджет будь-якої країни складається 3 доходів та видатків. Склад доходів визначає економічна основа держави, а видатків - функції держави. Основними доходними джерелами бюджету є податкові платежі та всі види державного мита. Кожна держава прагне реально оцінювати свої фінансові можливості та контролювати витрати уряду, які не повинні перевищувати доходи. Тобто для контролю законодавчої гілки влади над виконавчою запроваджено інститут парламентського контролю. Для здійснення фінансових засобів парламентського контролю в багатьох державах $\mathrm{CC}$, як і в Україні, створено спеціальні органи - рахункові палати, діяльність яких повинна відповідати стандартам міжнародної та європейської організації вищих органів фінансового контролю (INTOSAI та EUROSAI). Однак аналіз діяльності Рахункової палати в Україні виявив низку проблем, що спонукає звернутися до зарубіжного досвіду іiї функціонування. Цей досвід українськими фахівцями у сфері державного управління, особливо в порівнянні $з$ досвідом аналогічного органу в Україні, досліджений недостатньо.

Аналіз останніх досліджень і публікацій. Серед вітчизняних дослідників, які торкаються питань парламентського контролю в Україні, 
згадаємо таких, як В. Бакуменко, Ю. Барабаш, В. Журавський, К. Закоморна, С. Ківалов, О. Майданник, І. Словська, С. Сорока. Вони, зокрема, розглядають питання теорії контрольної функції парламенту, розкривають конституційні засади парламентського контролю, аналізують проблеми законодавчого забезпечення діяльності Верховної ради у сфері контролю. В. Шаповал наголошує, що парламентський контроль - «це одна 3 функцій парламенту, у широкому розумінні - діяльність парламенту, його органів і посадових осіб, а також інших державних органів та посадових осіб, з відповідною метою функціонально поєднаних із парламентом, у здійсненні повноважень контролю за виконавчою владою, насамперед урядом. Зазвичай до змісту контрольної функції парламенту відносять його діяльність щодо контролю за виконанням державного бюджету. Іноді цю діяльність вважають складником бюджетної функції законодавчого органу» [6].

Російські вчені В. Біляєв, А. Корнілаєва, Н. Нижник, Б. Страшун, В. Чиркін, М. Утяшев аналізують контроль у контексті загальної теорії управління, яка розглядає контроль як невід'ємну функцію й одну зі стадій процесу управління, а функції парламентів тісно пов'язують із їхніми повноваженнями.

Постановка завдання. Мета статті - на прикладі діяльності рахункових палат у Німеччині, Франції, Фінляндії та Україні виявити інституційні особливості та проблеми реалізації фінансово-економічного контролю, виокремити позитивний досвід і проаналізувати можливості його впровадження в Україні.

Виклад основного матеріалу дослідження. Діяльність Федеральної аудиторської служби (далі - ФАСН) в Німеччині (Федеральний аудиторський суд) регулюється на конституційному рівні. Вона діє відповідно до ст. 114 п. 2 Основного закону Федеративної Республіки Німеччини, в якому зазначено, що ФАСН, як і суди, незалежна у своїй діяльності, а ії члени перевіряють звіти, а також рентабельність і правильність управління в економічній та фінансовій сферах [11]. Кожного року ФАСН повинна інформувати про свою діяльність Уряд, Бундестаг, Бундесрат.

Відповідно до § 3 закону «Про Федеральну аудиторську службу» членами ФАСН є президент, віце-президент, керівники підрозділів експертиз та керівники груп [10]. Завдання функціонування палати прописані у Федеральному бюджетному кодексі [8]. Відповідно до $\S 88$ все управління бюджетом та господарством ФРН, включно з іï спеціальними активами та фондами, підлягає аудиту ФРП. Окрім аудиту, на підставі його висновків, Аудиторська служба може також консультувати Бундестаг, Бундесрат, Федеральний уряд та окремі Федеральні міністерства (п. 2 § 88).

Відповідно до § 89 ФАСН має право перевіряти доходи, витрати, зобов'язання з оплати, аванси, використання коштів, виділених на самоврядування. Зміст аудиту охоплює дотримання правил та принципів управління бюджетом та економічним управлінням, зокрема: чи дотримувався закон, доходи та витрати виправдані та доведені, а рахунки та звіт про активи складені належним чином тощо (§ 90).

Федеральна аудиторська служба також визначає час і характер експертизи і проводить необхідні дії (§ 94). При цьому вона може консультуватися з експертами, запитувати всі необхідні для виконання їі обов'язків документи, які повинні бути надіслані протягом певного періоду. Уся інформація має бути надана ФАСН та іiі членам в обов'язковому порядку.

Окремо відзначимо консультативну функцію ФАСН. Так, перед прийняттям адміністративних норм щодо виконання Федерального бюджетного кодексу з ФАСН проводиться обов'язкова консультація (п. 1 § 103) [8]. Адміністративні ж положення включають загальні інструкції щодо адміністрування коштів та платіжних агентств, обліку та підтвердження активів. Перш ніж схвалювати рішення про прийняття або зміну правил щодо бюджетної системи, компетентне Федеральне міністерство заслуховує ФАСН (п. $3 \S 103$ ).

ФАСН контролює різні сфери діяльності уряду. Зокрема, інформація на офіційному сайті стосується таких тем, як-от: зміна клімату, податки, будівництво, інформація про розвиток бюджетних планів на 2020 р., стан запобігання корупції у сфері бізнесу Федерального міністерства транспорту та цифрової інфраструктури тощо. ФАСН також аналізує бюджетне та економічне управління Федерального уряду, зокрема щорічні доходи та видатки на суму понад 700 мільярд євро. Очолює ФАСН Федеральний комісар (сьогодні - Кей Шеллер) [15].

Під час виконання своїх повноважень ФАСН оприлюднює щорічні звіти, доповіді консультантів, спеціальні доповіді, звіти експертів, спільні звіти 3 органами аудиту. На офіційному сайті ФАСН міститься перелік зауважень із боку останньої до відповідних структур. Наприклад, серед останніх зауважень 2019 р. є два зауваження, адресовані управлінню фінансів (№ 27 - про те, 
що допомога для фермерів та лісників не досягає своєї мети; № 26 - про необхідність запобігти втраті податку 3 продажів в аеропортах Німеччини); або ж адресоване управлінню інформаційних технологій зауваження № 21, в якому йдеться про те, що Федеральний відділ управління з радіаційної безпеки легковажить IT-безпекою [15].

Окремої уваги заслуговує звітність ФАСН. Зокрема, звіт за 2019 р. щодо бюджету - це всього 25 сторінок, де знаходимо не тільки перелік видів виконаної роботи, а й конкретні рекомендації щодо вдосконалення економічної та фінансової діяльності, як-от: у п. 3.2 розглянуто питання введення нового податку: «Для задоволення потреб Федерального бюджету, які інакше не можуть бути забезпечені, та щоб уможливити законодавчим органам та Федеральному уряду проведення гнучкої податково-бюджетної політики, адаптованої до відповідної економічної ситуації і бюджетних потреб, пропонується ввести новий податок на прибуток» [7].

ФАСН займається не тільки аудиторською діяльністю, а й аналітичною. Палата здійснює аналіз чинного законодавства, а також розробляє законопроекти для нових законів. Зауважимо, що iii рекомендації та звіти мають вирішальну роль для здійснення оцінки діяльності уряду [12]. Це може призвести в деяких випадках до усунення відповідних міністрів $з$ посади.

У Франції діяльність Рахункової палати забезпечується відповідно ст. 47-6 Конституції, в якій зафіксовано: «Рахункова палата допомагає парламенту контролювати виконання фінансових законів, а також застосовувати закони про соціальне забезпечення та оцінювати державну політику. За допомогою публічних звітів інформує громадян про свою діяльність» [9].

Рахункова палата Французької республіки (далі - РПФР) (ії також іноді називають Рахунковим судом) складається з Генерального секретаріату, до якого входять магістрати, розділені на 6 палат. Генеральний секретаріат відповідає за управління Палатою. При Палаті діє Генеральна прокуратура, яку очолює генеральний прокурор. Рахункова палата здійснює 4 основні місії: суду може притягти до особистої та матеріальної відповідальності державних бухгалтерів; контролю - контролює діяльність органів соціального забезпечення, державних підприємств, організацій; звітування - кожного року готує звіт для держави, надає громадянам фінансову інформацію; оцінки - надає допомогу урядові та парламенту в оцінці державної політики. Вона прагне встановити пропорційність поставлених цілей до результатів, відстежити ефективність використання бюджетних коштів. Палата оцінює наслідки та надає рекомендації щодо вибраних парламентом цілей. Отже, органи державної влади можуть базувати свої рішення на об'єктивному аналізі, здійсненому РПФР.

Основним завданням РПФР $є$ забезпечення належного використання державних коштів та інформування громадян. Компетенція Палати поширюється на близько тисячі рахунків державних бухгалтерів, при цьому відзначимо, що під час перевірки правильності ведення рахунків державними органами ревізори мають доступ до всіх адміністративних та облікових документів цих органів.

Фактично РПФР забезпечує регулярність та ефективність управління у французькій державі. Для цього вона не тільки контролює державу, організації соціального захисту, державні підприємства, організації, які отримують пожертви, медичні соціальні установи та приватні клініки, а й публікує офіційні звіти та актуальні матеріали 3 фінансової тематики з пропозиціями щодо удосконалення управління [16]. Наприклад, РПФР на чолі з Дідьє Мігу в Офіційному звіті за 2018 р. проаналізувала прогноз уряду щодо ймовірного показника дефіциту державного бюджету ВВП. Проект закону «Про Бюджет на 2019 рік» передбачав збільшення державного дефіциту, головно через надання податкового кредиту для забезпечення конкурентоспроможності та зайнятості разом зі зниженням величини внесків, які тимчасово та у виняткових випадках збільшують дефіцит.

Натомість прийняті наприкінці 2018 р. заходи 3 підтримки купівельної спроможності домогосподарств призвели до зниження державного дефіциту. У висновку РПФР звернено увагу на крихкість перспектив державних фінансів на 2019 р.: «У 2019 р. структурний дефіцит буде в найкращому разі стабільним, а державний борг щодо ВВП знову збільшиться, що суперечить положенням Закону «Про програмування державних фінансів»» [14]. Наголошувалося, що «лише частина заходів на користь підвищення купівельної спроможності домашніх господарств була включена до закону «Про бюджет». Отож, дотримання прогнозу державного балансу передбачає, що заходи, які містяться в Законі «Про екстрені економічні та соціальні заходи», прийнятому наприкінці 2018 р., які збільшують дефіцит на 3,7 млрд євро, компенсують оголошені урядом економія 
та додаткові доходи» [14]. Але останні потрібно унормувати, перевести в законодавчі положення. Тобто РПФР не тільки вказує на проблему, а й пропонує шляхи ії вирішення.

У Фінляндії про контроль парламенту (Едускунти) за державними фінансами, виконанням державного бюджету йдеться в ст. 90 Конституції [17]. Для цього створено незалежну від інших гілок влади Рахункову палату (Державне ревізійне управління) з державних ревізорів, обраних із-поміж членів Едускунти.

Державні ревізори та Рахункова палата мають право отримувати від державних органів усі необхідні відомості для виконання своїх обов'язків. Відповідно до § 1 Закону «Про Рахункову палату» цей орган несе відповідальність за перевірку законності та доцільності управління фінансами держави [13]. Насамперед Рахункова палата перевіряє ефективність та законність дій уряду щодо розпорядження державними фінансами, проте має й таке досить нетрадиційне повноваження, як здійснення контролю фінансування виборів та політичних партій. Наприклад, іiі звіт засвідчує, що під час парламентських виборів 2019 р. жодного порушення в цій сфері не виявлено.

Палата має право перевіряти органи державної влади, державні компанії, кредитні установи, активи, що перебувають у власності держави, юридичних осіб, яких держава уповноважила проводити збір коштів для певної мети, тощо. Перевірка може здійснюватися безпосередньо в приміщенні певного органу, кредитної установи та ін. Відповідно до § 6 до кінця вересня кожного року Рахункова палата звітує перед парламентом.

Заслуговує на увагу програмна назва Розділу 3 Річного звіту за 2018 р. - «Прозорість $\epsilon$ основою належного урядування та управління фінансами». Аналізуючи стан законності та регулярності роботи Відомства 3 нарахування заробітної плати для бухгалтерських служб, державні ревізори відзначали відповідність нарахування заробітної плати законодавству та колективним договорам. Водночас вони наголошували на першочерговості завдання - поліпшити контроль за запобіганням помилок. Тобто основний акцент в управлінні зроблено на попередженні ймовірних хибних дій, оскільки «відомство несе відповідальність за надання своєчасної інформації до Сервісного центру (відповідає за технічне нарахування оплати праці), на основі якої нараховується заробітна плата» [18].

Ефективна діяльність Палати зумовила проведення в столиці - м. Гельсінкі - у квітні 2018 р. в межах діяльності робочої групи EUROSAI WGEA практичного семінару з питань управління природоохоронною діяльністю, під час якого експерти з різних країн поділилися досвідом проведення Рахунковою палатою аудитів у сфері досягнення цілей сталого розвитку та коштів, виділених на попередження та ліквідацію наслідків катастроф [2].

В Україні, після тривалих, упродовж двох десятиліть, парламентсько-судових дискусій, сподіваємось, що нарешті остаточно зафіксовано в ст. 98 Конституції повноваження Рахункової палати (далі - РПУ) здійснювати парламентський контроль не лише за використанням, а й за надходженням коштів до Державного бюджету [3]. Рішеннями Конституційного Суду України (1997 p., 2010 р.,) можливість контролю за доходною частиною Бюджету ця стаття то передбачала, то вилучала з їі тексту.

Станом на 1 січня 2020 р. у ст. 110 Бюджетного кодексу України (далі - БКУ) «Повноваження Рахункової палати 3 контролю за дотриманням бюджетного законодавства» вже зафіксовано «здійснення контролю за надходженням та використанням коштів до Державного бюджету України, <..> за утворенням, обслуговуванням i погашенням державного боргу, ефективністю управління коштами, використанням коштів місцевих бюджетів у частині трансфертів, що надаються 3 державного бюджету, а також за надходженням закріплених за місцевими бюджетами загальнодержавних податків і зборів» [1]. Аудит фінансової діяльності органів влади на місцевому рівні став можливим унаслідок реалізації реформи місцевого самоврядування та децентралізації. Також на РПУ покладено обов'язок щоквартального звітування (п. 2. ст. 110) щодо виконання держбюджету та подання пропозицій щодо усунення порушень, а також річного звіту, де повинні бути вказані пропозиції щодо «вдосконалення бюджетного процесу загалом» (ст. 62).

Важливе значення має закріплення в Законі України «Про Рахункову палату» [5] засадничих принципів здійснення зовнішнього фінансового контролю (законність, плановість, об'єктивність, незалежність і гласність), оскільки в інших численних нормативних актах щодо державного фінансового контролю вони відсутні. Як державний конституційний орган спеціальної юрисдикції РПУ реалізує не тільки контрольну функцію щодо ВРУ, Національного банку України, Антимонопольного комітету, Фонду державного майна, органів виконавчої влади, всіх державних органів та установ, ай функцію експертизи їхньої 
діяльності. Очільник РПУ В. Пацкан наголосив: «Проведення якісних аудитів з урахуванням міжнародних стандартів 3 обгрунтованими та чіткими рекомендаціями повинно комплексно відображати проблеми тієї чи іншої сфери» [2, с. 3]. Однак у законі РПУ не закріплена як вищий орган фінансового контролю, що не дозволяє повністю поширити на іiі діяльність положення Лімської декларації, в ст. 20 якої вказано: «Вищий орган фінансового контролю повинен бути уповноважений здійснювати максимально широку перевірку сплати податків і в ході перевірки переглядати особисті досьє про сплату податків» [4].

Новітніми реаліями реформування РПУ $\epsilon$ створення 8 управлінь у регіонах України (у містах Київ, Дніпро, Львів, Одеса, Харків, Вінниця, Ужгород (на стадії створення)), які покликані забезпечувати незалежний від місцевих органів влади зовнішній контроль бюджетів як на стадії ï проектування, так і виконання. Донедавна на регіональному рівні він був практично відсутній, оскільки управління фінансової інспекції підпорядковані місцевим органам влади.

На відміну від аналогічних документів розглянутих вище рахункових палат, обсяг щорічного звіту РПУ перевищує обсяг закордонних у рази і становить 157 с. та розкриває діяльність щодо реалізації 17 напрямів зовнішнього аудиту. Це свідчить як про недосконалість нормування, планування та реалізації бюджетного процесу, так i про величезну кількість його порушень унаслідок численних причин. Так, протягом 2018 р. РПУ було перевірено 598 об'єктів, державних коштів на суму 304,7 млрд грн, виявлено порушень і недоліків на суму 17 млрд грн [2, с. 10]. Як окремий приклад наведемо рекомендацію РПУ Кабінетові міністрів щодо подолання тенденції зростання місцевих бюджетів від отримання трансфертів із державного бюджету. Зокрема, було запропоновано «ініціювати внесення змін до ст. 29 та глави 11 «Надходження та витрати місцевих бюджетів» БКУ щодо передачі частини загальнодержавних податків або збільшення часток відрахувань окремих податків, які справляються на відповідній території, для посилення фінансової спроможності місцевих бюджетів» [2, с. 18]. Унаслідок таких дій «з 1 січня 2019 р. до бюджетів місцевого самоврядування за місцем видобутку відповідних корисних копалин додатково зараховується 5\% рентної плати за користування надрами для видобування корисних копалин загальнодержавного значення, ... а з 2019 р. ресурс місцевих бюджетів збільшився щонайменше на 0,1 млрд грн на рік» $[2$, c. 18$]$.

Натомість проведений РПУ аудит ефективності засвідчив, що проведення пісенного конкурсу «Свробачення - 2017» відбулося не лише із численними порушеннями використання бюджетних коштів (554,2 млн грн із загальної суми 787 млн грн), а й неефективно (171,8 млн грн) [2, с. 80-81].

Висновки. Отже, діяльність рахункових палат у Німеччині, Франції, Фінляндії та Україні свідчить про поступове їх інституційне уподібнення як органів парламентського контролю, наближення до міжнародних та європейських стандартів фінансового контролю, поступовий перехід до виконання функції фінансово-економічного контролю в контексті ефективності використання бюджетних коштів. Донедавна контрольна діяльність РПУ була малоефективна, непрозора, здійснювалася лише на національному рівні. Здійснення реформи місцевого самоврядування та відповідне реформування РПУ уможливило iii функціонування на регіональному рівні в територіальних управліннях.

Із позитивного закордонного досвіду для впровадження в Україні можна рекомендувати: в умовах парламентсько-президентської форми правління розширити сфери впливу РПУ не тільки на управління бюджетом, а й на всю економічну діяльність; закріпити за РПУ функцію попереднього консультування щодо фінансової діяльності; передбачити в організаційній структурі РПУ орган прокуратури; закріпити за РПУ повноваження контролю фінансування виборів та політичних партій.

Список літератури:

1. Бюджетний кодекс України від 8.07.2010 p. Зі змінами станом на 1.01.2020 p. URL: https://zakon.rada.gov.ua/laws/show/2456-17

2. Звіт Рахункової палати за 2018 рік. Київ, 2019. 157 с. URL: https://rp.gov.ua/upload-files/Activity/ Reports/2018/ZVIT_RP_2018.pdf

3. Конституція України від 28.06.1996 p. Зі змінами станом на 1.01 .2020 p. URL: https://zakon.rada.gov.ua/laws/show/254\%D0\%BA/96-\%D0\%B2\%D1\%80

4. Лімська декларація керівних принципів контролю від 1 січня 1977 року 604_001. URL: https://zakon.rada.gov.ua/laws/show/604_001. 
5. Про Рахункову палату :Закон України від 02.07.2015 p. URL: https://zakon.rada.gov.ua/laws/show/576-19

6. Юридична енциклопедія / за ред. Ю. С. Шемшученко. Київ : «Українська енциклопедія» ім. П.М. Бажана, 2009. Т. 3. С. 324.

7. Bericht des Bundesbeauftragten der Bundesrechnungshof. 2018. URL: https://www.bundesrechnungshof. de/de/veroeffentlichungen/produkte/gutachtenberichtebwv/berichte/langfassungen/2019-bwv-gutachten-abbaudes-solidaritaetszuschlages-pdf

8. Bundeshaushaltsordnung. 11.08.1969. URL: http://www.gesetze-im-internet.de/bho/index.html

9. Constitution de la République française. 04.10.1958. URL: http://www.assemblee-nationale.fr/connaissance/ constitution.asp

10. Gesetz über den Bundesrechnungshof. 11.07.1985. URL: http://www.gesetze-im-internet.de/brhg_1985/ index.html

11. Grundgesetz für die Bundesrepublik Deutschland. 23.05.1949. URL: http://www.gesetze-im-internet.de/ gg/GG.pdf

12. Informationsbroschüre «Der Bundesrechnungshof». URL: https://www.bundesrechnungshof.de/de/ueberuns/informationsbroschuere

13. Laki valtiontalouden tarkastusvirastosta. 14.07.2000. URL: https://www.finlex.fi/fi/laki/ ajantasa/2000/20000676

14. Le rapport public annuel. 2018. URL: https://www.ccomptes.fr/fr/publications/le-rapport-publicannuel-2018

15. Offizielle Website des Bundesrechnungshof. URL: https://www.bundesrechnungshof.de/de/ veroeffentlichungen/suchen-filter\#b_start $=0$

16. Site officiel Cour des comptes. URL: https://www.ccomptes.fr/fr

17. Suomen perustuslaki alkaen. 11.06.1999. URL: http://www.finlex.fi/fi/laki/ajantasa/1999/19990731

18. Valtiontalouden tarkastusviraston vuosikertomus eduskunnalle. 2018. URL: https://www.vtv.fi/app/ uploads/2018/09/06155752/VTV_Vuosikertomus-eduskunnalle_2018_K192018vp.pdf

\section{Yuriychuk Ye.P., Svirniuk N.V. INSTITUTIONAL FEATURES OF THE AUDIT CHAMBER AS A SUBJECT OF PARLIAMENTARY CONTROL IN THE EU AND UKRAINE}

The article analyzes the activity of a special body for the implementation of parliamentary control - the Audit Chamber in Germany, France, Finland and Ukraine, which testifies to their gradual institutional similarity, approximation to the international and European standards of financial control, gradual transition to performing the function of financial and economic control in the context of efficiency of the budgetary funds use. Until recently, the control activity of the Audit Chamber of Ukraine (ACU) was ineffective, nontransparent, carried out only at the national level solely by means of the use of the State budget funds.

The parliamentary audit of the financial activity of local authorities became possible due to the implementation of local self-government reform and decentralization through the functioning of territorial administrations in the regions of Ukraine, which are intended to provide external control of budgets independently from local authorities both at the stage of their drafting and implementation.

Taking into account the positive foreign experience it can be recommended for implementation in Ukraine: to expand the sphere of influence of the ACU not only on budget management but also on all economic activity in the conditions of the parliamentary-presidential form of the government; to assign the function of preliminary advice on financial activities to the ACU; to provide a prosecutorial authority in the organizational structure of the ACU; to assign control over election and political parties funding to the ACU.

Key words: control, parliamentary control, financial control, control bodies, Audit Chamber, constitutionalism. 